\title{
Specific Serological Relationships Among Partially Purified DNA Polymerases of Avian Leukosis-Sarcoma Viruses, Reticuloendotheliosis Viruses, and Avian Cells
}

\author{
SATOSHI MIZUTANI AND HOWARD M. TEMIN \\ McArdle Laboratory for Cancer Research, University of Wisconsin, Madison, Wisconsin 53706
}

Received for publication 3 December 1973

\begin{abstract}
Specific serological relationships were found among the partially purified DNA polymerases of the two groups of avian viruses whose virions contain RNA and a DNA polymerase - the avian leukosis-sarcoma viruses and the reticuloendotheliosis viruses-and three avian species which are natural hosts for these viruses: chickens, turkeys, and Pekin ducks. No relationships were found to DNA polymerases of HeLa cells or Escherichia coli. These results are consistent with the hypothesis that RNA viruses with a DNA polymerase originated from normal cellular components.
\end{abstract}

The reticuloendotheliosis viruses (REV)chicken syncytial virus (CSV), duck infectious anemia virus (DIAV), reticuloendotheliosis virus (strain T) (REV-T), and Trager duck spleen necrosis virus (TDSNV)-are a newly described group of avian RNA viruses (8). REV virions are enveloped, have C-type morphology, and contain 60 to $70 S$ RNA and a DNA polymerase $(3,4,7)$. Their replication requires a replicative cell cycle and involves a DNA intermediate (12; Kang, personal communication; Cooper, personal communication). However, in spite of these characteristics, REV are not classified as members of the avian leukosis-sarcoma virus group (ALV). The virions of ALV and REV are antigenically distinct (2); there is apparently no genetic or physiological interaction between REV-T and ALV (2); the DNA polymerase activity of disrupted virions of REV and ALV are serologically distinct (5); and there is little or no detectable nucleic acid sequence homology between RNAs of ALV and REV (3).

However, our hypothesis that RNA viruses which replicate through a DNA intermediate arose from normal cellular components $(10 ; \mathrm{H}$. M. Temin, Advan. Cancer Res., 19:47-104, 1974) prompted us to examine the partially purified DNA polymerases of REV and ALV virions and of chickens, Pekin ducks, and turkeys for serological relationships. This paper reports such relationships.

\section{MATERIALS AND METHODS}

Viruses. The viruses used have been described previously (5). Carr-Zilber associated virus (CZAV) was a kind gift of David Boettiger. The viruses were grown in chicken or pheasant embryo fibroblasts and were purified by the methods described previously (5). No contamination (less than $0.01 \%$ ) of TDSNV, REV-T, and CSV preparations by ALV and no contamination (less than $0.01 \%$ ) of RSV-RAV-0 preparations by REV was found by nucleic acid hybridization (Kang, personal communication).

Isotopes and other chemicals. $\left[{ }^{3} \mathrm{H}\right] \mathrm{dTTP} \quad(18$ $\mathrm{Ci} / \mathrm{mmol})$ was purchased from Schwarz/Mann (Orangeburg, N.Y.). Calf thymus DNA, RNase A (EC 2.7.7.16), and bovine serum albumin were purchased from Worthington, Freehold, N.J. Human gamma globulin was purchased from Nutritional Biochemicals, Inc., Cleveland, Ohio.

Purification of DNA polymerases. Two chicken embryo DNA polymerases, one $10 S$ (S3-L) and one 3 to $4 S(\mathrm{~S} 3-\mathrm{S})$ in size, were partially purified from the soluble fraction of homogenates of chicken embryos as previously described (5).

DNA polymerases were partially purified from Muscovy duck, Pekin duck, pheasant, turkey, and rat livers by the following steps. A liver (39 g) from a Muscovy duck, a liver $(20 \mathrm{~g})$ from a Pekin duck, a liver (18 g) from a ring-necked pheasant, and a liver (100 g) from a turkey, all obtained from local farmers, and several livers (100 g) from Fisher rats (Charles River Breeding Laboratory) were washed with phosphate-buffered saline ( $\mathrm{pH}$ 7.0) and were homogenized with a motor-driven Teflon-glass Potter-Elvejhem homogenizer in $0.02 \mathrm{M}$ Tris-hydrochloride ( $\mathrm{pH} 7.5)$ containing $0.25 \mathrm{M}$ sucrose, $0.01 \mathrm{M} \mathrm{KCl}, 0.005 \mathrm{M}$ $\mathrm{MgCl}_{2}$, and $0.005 \mathrm{M}$ 2-mercaptoethanol. The homogenates were centrifuged at $105,000 \times g$ for $1 \mathrm{~h}$ at $4 \mathrm{C}$. The supernatants were adsorbed to phosphocellulose columns ( 3 by $10 \mathrm{~cm})$ (P-1, Whatman) equilibrated with $0.02 \mathrm{M}$ Tris-hydrochloride ( $\mathrm{pH} 8.0$ ) containing 0.001 M EDTA, 0.005 M 2-mercaptoethanol, 30\% (vol/vol) glycerol, and $0.2 \%$ Triton X-100 (buffer A). After washing with $50 \mathrm{ml}$ of buffer A, the DNA polymerase activities were eluted with $0.5 \mathrm{M} \mathrm{NaCl}$ in 
buffer A. Fractions containing DNA polymerase activity were pooled and were concentrated to $8 \mathrm{ml}$ with a Diaflo apparatus (PM-10, Amicon). The concentrated fractions were loaded on Sephadex G-100 columns $(2.5$ by $30 \mathrm{~cm})$ equilibrated with $0.02 \mathrm{M}$ Tris-hydrochloride ( $\mathrm{pH} 7.5$ ) containing $0.5 \mathrm{M} \mathrm{KCl}$, 0.001 M EDTA, 0.005 M 2-mercaptoethanol, and 10\% (vol/vol) glycerol. Each DNA polymerase activity was separated into two peaks. Each peak was concentrated with a Diaflo apparatus (PM-10, Amicon), was layered on a 15 to $45 \%(\mathrm{vol} / \mathrm{vol})$ glycerol gradient containing $0.5 \mathrm{M} \mathrm{KCl}, 0.02 \mathrm{M}$ Tris-hydrochloride ( $\mathrm{pH}$ 8.0 ), and $0.005 \mathrm{M}$ dithiothreitol, and was centrifuged at $50,000 \mathrm{rpm}$ for $15 \mathrm{~h}$ at $4 \mathrm{C}$ in a SW 50.1 rotor (Beckman) as described in the legend of Fig. 1. The large DNA polymerases isolated from the Muscovy duck, Pekin duck, pheasant, turkey, and rat livers sedimented at 8 to $9 S$, and all the small DNA polymerases sedimented at 3 to $4 S$. All the sedimentation values are relative to $\mathrm{RNase} A\left(\mathrm{~s}_{20, w} 2.0\right)$, bovine serum albumin $\left(s_{20, w} 4.6\right)$, and human gamma globulin $\left(s_{20 . w} 7.1\right)$ sedimented in a parallel gradient. Approximately a 200 - to 300 -fold purification was attained by these procedures.

DNA polymerases were partially purified from purified virions of RSV-RAV-0, CZAV, REV-T, TDSNV, and CSV as previously described (5). Unless otherwise stated, all DNA polymerases were centrifuged in glycerol gradients containing $0.5 \mathrm{M} \mathrm{KCl}$.

Purified DNA polymerase I (fraction VI) from Escherichia coli was kindly supplied by Robert Wells. Partially purified DNA polymerase from HeLa cells was kindly supplied by S. Seki. It was purified by phosphocellulose column chromatography and glycerol gradient centrifugation. It sedimented at 8 to $9 S$ in a gradient like that of Fig. 1 .

Antibodies. Antibodies against avian myeloblastosis virus (AMV) DNA polymerase, chicken embryo large (10S) DNA polymerase (S3-L), and chicken embryo small (3 to $4 S$ ) DNA polymerase (S3-S) have been described previously $(5,6)$. Antibodies against RSV-RAV-0 and TDSNV DNA polymerases were made in $(\mathrm{W} / \mathrm{Fu} \times \mathrm{BN}) \mathrm{F}_{1}$ hybrid rats by the method described by Nowinski et al. (6) except that the amount of DNA polymerase per injection was 10 to 20 $\mu \mathrm{g}$. IgG was isolated from each antiserum with the use of a Sephadex G-200 column. Antibodies against AMV, chicken embryo large, chicken embryo small, RSV-RAV-0, and TDSNV DNA polymerases are called IgG-AMV, IgG-L, IgG-S, IgG-RSV-RAV-0, and IgG-TDSNV, respectively.

Antibody activity of IgG-RSV-RAV-0 and IgGTDSNV was examined with detergent-disrupted virions of avian leukosis-sarcoma viruses and reticuloendotheliosis viruses. A $0.3-$ to $0.5-\mu \mathrm{g}$ amount of Nonidet P-40 disrupted virions of each virus was incubated with 5 or $50 \mu \mathrm{g}$ of each antibody in $25 \mu$ liters at room temperature for $30 \mathrm{~min}$. DNA polymerase activity remaining was assayed as $\left[{ }^{3} \mathrm{H}\right.$ ]TMP incorporation into trichloroacetic acid-insoluble counts with activated calf thymus DNA as a template primer. IgG-RSV-RAV-0 $(50 \mu \mathrm{g})$ neutralized the DNA polymerase activities (over $90 \%$ ) of disrupted virions of all ALVs tested (RSV-RAV-0, RSV-RAV-60, RAV-0, and
B77V). It did not neutralize the DNA polymerase activities of disrupted REV virions (CSV, REV-T, and TSDNV) or chicken embryo large and small DNA polymerases (data not shown).

IgG-TDSNV $(5 \mu \mathrm{g})$ neutralized the DNA polymerase activities of disrupted virions of CSV, REV-T, and TDSNV (data not shown). However, the DNA polymerase activities of disrupted virions of avian leukosissarcoma viruses (RSV-RAV-0, RSV-RAV-60, RAV-61, RAV-0, and B77V) were not neutralized even by $50 \mu \mathrm{g}$ of antibody (data not shown).

DNA polymerase assay. Unless otherwise indicated, a standard DNA polymerase assay was used (13). A $100-\mu \mathrm{g} / \mathrm{ml}$ amount of activated calf thymus DNA (9) was used as template primer. All reactions were carried out in volumes of $125 \mu$ liters in the wells of plastic microtiter plates (IS-MRC-96) (Linbro Chemical Co., New Haven, Conn.) covered with Scotch tape and floated in a water bath. The $\left[{ }^{3} \mathrm{H}\right] \mathrm{dTTP}$ used was 5,000 counts per min per pmol.

\section{RESULTS}

Size of REV DNA polymerases. Partially purified TDSNV DNA polymerase was centrifuged in linear 15 to $45 \%$ ( $\mathrm{vol} / \mathrm{vol})$ glycerol gradients containing 0.05 or $0.5 \mathrm{M} \mathrm{KCl}$ (Fig. 1). In the gradient containing $0.05 \mathrm{M} \mathrm{KCl}$, the TDSNV DNA polymerase sedimented in a broad peak faster than the bovine serum albumin marker. In the gradient containing $0.5 \mathrm{M}$ $\mathrm{KCl}$, the TDSNV DNA polymerase sedimented as a sharp band at the position of the bovine serum albumin marker. The differences in the sedimentation patterns of TDSNV DNA polymerase at these two salt concentrations may be due to aggregation, or change in conformation of the DNA polymerase, or both.

The sedimentation patterns of REV-T DNA polymerase in gradients containing $0.05 \mathrm{M}$ or $0.5 \mathrm{M} \mathrm{KCl}$ were similar to those of TDSNV DNA polymerase (data not shown). However, this variation of sedimentation pattern with salt concentration was not found with all avian virus DNA polymerases. For example, partially purified RSV-RAV-0 DNA polymerase sedimented in glycerol gradients of several different salt concentrations with the same band width at the same position relative to marker proteins faster than human gamma globulin (data not shown).

From the similar sedimentation values of TDSNV and REV-T DNA polymerases and of bovine serum albumin in gradients containing $0.5 \mathrm{M} \mathrm{KCl}$, the molecular masses of TDSNV and REV-T DNA polymerases were roughly estimated as 70,000 daltons. The molecular mass of TDSNV DNA polymerase was also estimated as about 75,000 daltons from its rate of migration in a Sephadex G-200 column containing $0.5 \mathrm{M} \mathrm{KCl}$ (data not shown). The 


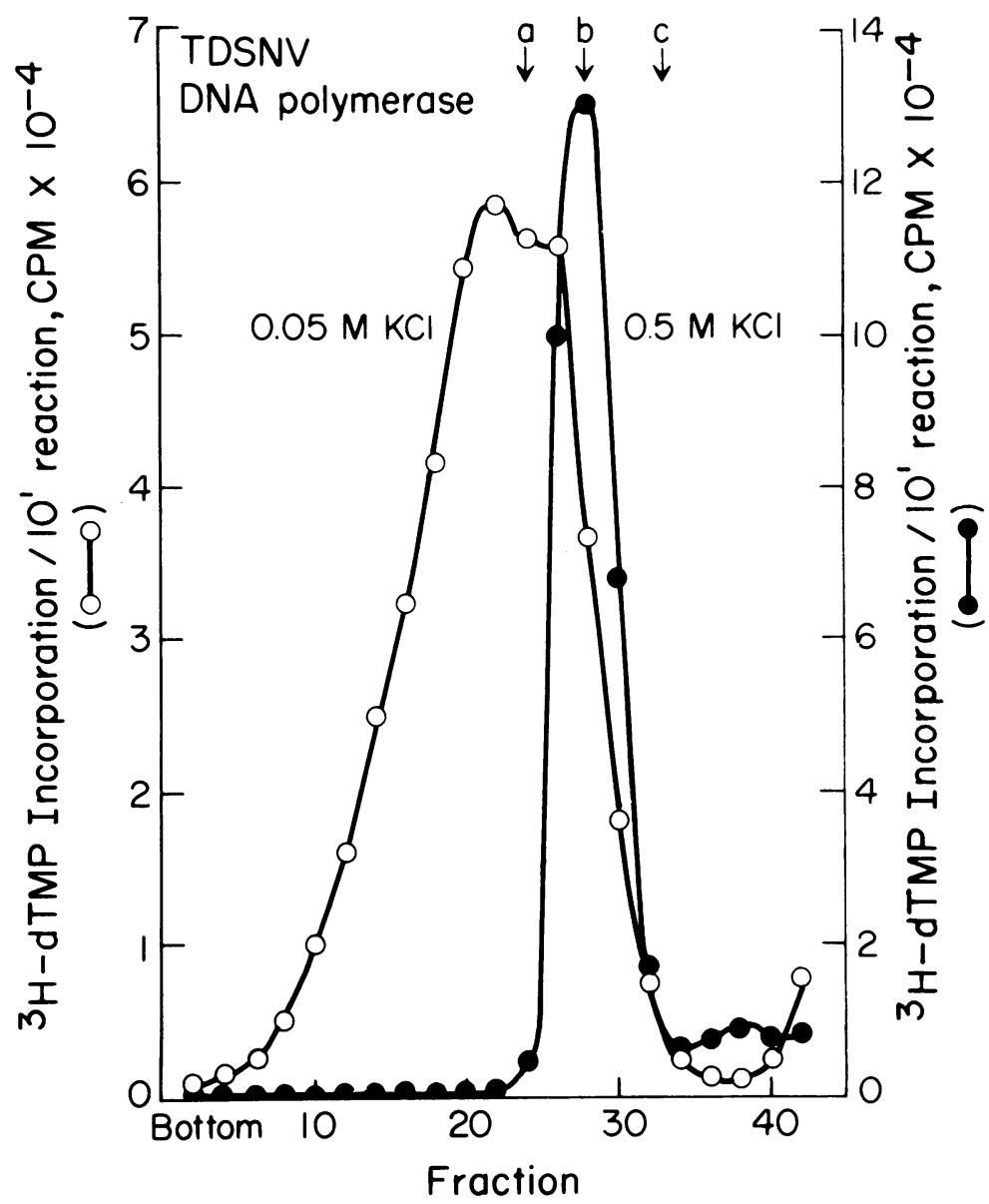

Fig. 1. Glycerol gradient centrifugation of partially purified TDSNV DNA polymerase. Linear 15 to $45 \%$ (vol/vol) glycerol gradients $(4.6 \mathrm{ml})$ in $0.02 \mathrm{M}$ Tris-hydrochloride (pH 8.0) containing $0.001 \mathrm{M} \mathrm{EDTA}, 0.005 \mathrm{M}$ dithiothreitol, and $0.05 \mathrm{M} \mathrm{KCl}(\mathrm{O})$ or $0.5 \mathrm{M} \mathrm{KCl}(\bigcirc)$ were prepared in tubes of a Spinco SW50.1 rotor. Enzyme solution $(0.5 \mathrm{ml})$ was loaded onto the gradients, and the gradients. were centrifuged in a Spinco $L$ centrifuge at $50,000 \mathrm{rpm}$ for $15 \mathrm{~h}$ at $5 \mathrm{C}$. The gradients were fractionated from the bottom. The DNA polymerase peaks were detected by a standard DNA polymerase assay containing activated calf thymus DNA. The positions of the protein markers (detected by Lowry assay) run in parallel gradients containing 0.05 or $0.5 \mathrm{M} \mathrm{KCl}$ are indicated by arrows: (a) human gamma globulin $\left(s_{20 . u^{\prime}} 7.1\right)$; $(b)$ bovine serum albumin $\left(s_{20 . w} 4.6\right)$; and $(c)$ ribonuclease $A$ $\left(s_{20, w} 2.0\right)$. (The relative positions of the protein markers were the same in the gradients containing 0.05 and 0.5 $\mathrm{MKCl}$.)

molecular masses of TDSNV DNA polymerase determined by these two methods were close to each other and were much smaller than the 110,000 to 180,000 daltons reported for avian leukosis-sarcoma virus DNA polymerases (11).

Neutralization of partially purified DNA polymerases of REV. Although previous studies using detergent-disrupted virions had not shown any serological relationships among DNA polymerases of REV, ALV, and chicken cells (5), the differences in sedimentation patterns in gradients with different salt concentrations (Fig. 1) suggested that different results might be found with partially purified REV
DNA polymerases. Therefore, samples of partially purified TDSNV DNA polymerase were incubated separately with IgG-TDSNV, IgGAMV, IgG-L, IgG-S, and IgG-RSV-RAV-0, and the amount of neutralization was determined. The results of these experiments are summarized in Fig. 2. TDSNV DNA polymerase activity was neutralized $80 \%$ by $10 \mu \mathrm{g}$ of IgG-TDSNV and 60 to $70 \%$ by 150 to $200 \mu \mathrm{g}$ of IgG-AMV or IgG-L. TDSNV DNA polymerase activity was not neutralized in this experiment by IgG-S or IgG-RSV-RAV-0. In other experiments using three different partially purified preparations of TDSNV DNA polymerase, the TDSNV DNA 


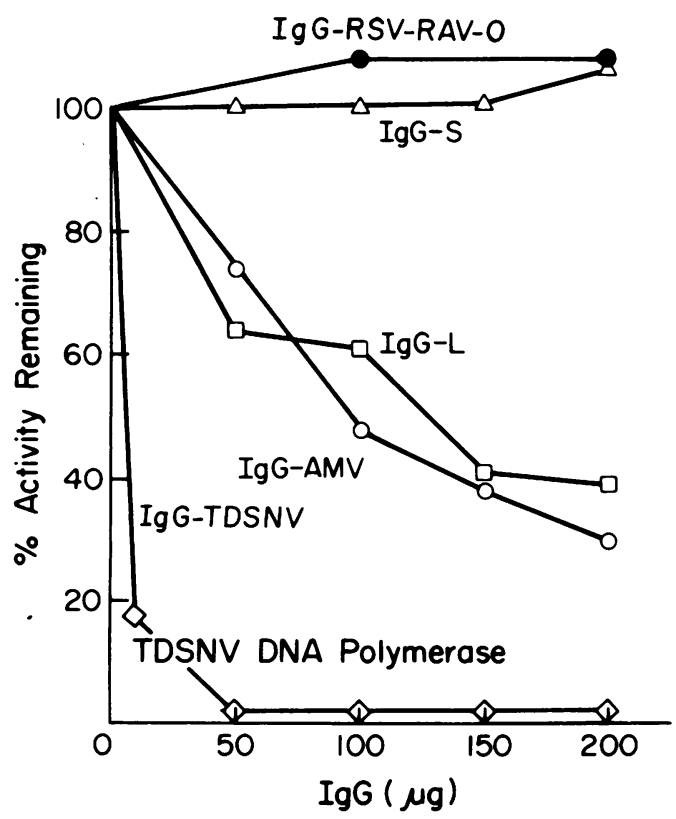

Fig. 2. Neutralization of partially purified

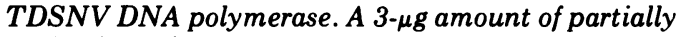
purified TDSNV DNA polymerase was incubated separately at room temperature for $30 \mathrm{~min}$ in 30 pliters of $0.17 \mathrm{M} \mathrm{KCl}$.with the indicated amounts of

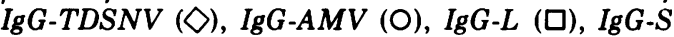
$(\Delta)$, or IgG-RSV-RAV-O (O). The amounts of DNA polymerase activity remaining were assayed in standard reaction mixtures containing activated calf thymus DNA. One hundred percent activity was 4,000 counts/min in a 20-min incubation.

polymerase activity was neutralized $20 \%$ by 200 $\mu \mathrm{g}$ of IgG-S (data not shown).

The amounts of IgG-AMV and IgG-L required to neutralize $50 \%$ of the activity of TDSNV DNA polymerase were about 100 times greater than the amounts of these antibodies required to neutralize $50 \%$ of the activity of the homologous DNA polymerase. For example, 1 $\mu \mathrm{g}$ of IgG-L neutralized $50 \%$ of the activity of the chicken embryo large DNA polymerase (5). Since IgG-S was about 10 -fold weaker than the other two antibodies, this relative amount of antibody was not available for use.

As a test for the possibility that the TDSNV DNA polymerase was contaminated by a chicken cell DNA polymerase, a mixture of approximately equal quantities (by a DNA polymerase activity measure) of TDSNV DNA polymerase and the chicken embryo large DNA polymerase was made, and an experiment similar to that shown in Fig. 2 was performed. In this mixture, $50 \%$ of the DNA polymerase activity was neutralized by $5 \mu \mathrm{g}$ of IgG-L (data not shown). Therefore, the results of Fig. 2 do not appear to be the result of contamination of the TDSNV DNA polymerase.

The neutralization of TDSNV DNA polymerase by IgG-AMV and by IgG-L appeared to be dependent upon the pretreatment of the TDSNV DNA polymerase. The activity of TDSNV DNA polymerase in disrupted virions or recovered from glycerol gradients containing $0.05 \mathrm{M} \mathrm{KCl}$ was not neutralized by $200 \mu \mathrm{g}$ of IgG-AMV or IgG-L. TDSNV DNA polymerase treated with $0.5 \mathrm{M} \mathrm{KCl}$ and then centrifuged in a glycerol gradient containing $0.05 \mathrm{M} \mathrm{KCl}$ was not neutralized by $200 \mu \mathrm{g}$ of IgG-AMV or IgG-L. These results may indicate that some saltdependent, reversible conformational changes occurred in the TDSNV DNA polymerase during purification.

Partially purified REV-T DNA polymerase was also incubated separately with the same antibodies, IgG-TDSNV, IgG-AMV, IgG-L, IgG-S, and IgG-RSV-RAV-0. The activity of partially purified REV-T DNA polymerase was neutralized $80 \%$ by $10 \mu \mathrm{g}$ of IgG-TDSNV, 50 to $60 \%$ by $200 \mu \mathrm{g}$ of IgG-AMV, IgG-L, and IgG-S, and $15 \%$ by $200 \mu \mathrm{g}$ of IgG-RSV-RAV-0 (Fig. 3).

On the other hand, the partially purified DNA polymerase of another member of the reticuloendotheliosis virus group, CSV, was not neutralized by $200 \mu \mathrm{g}$ of each of the four

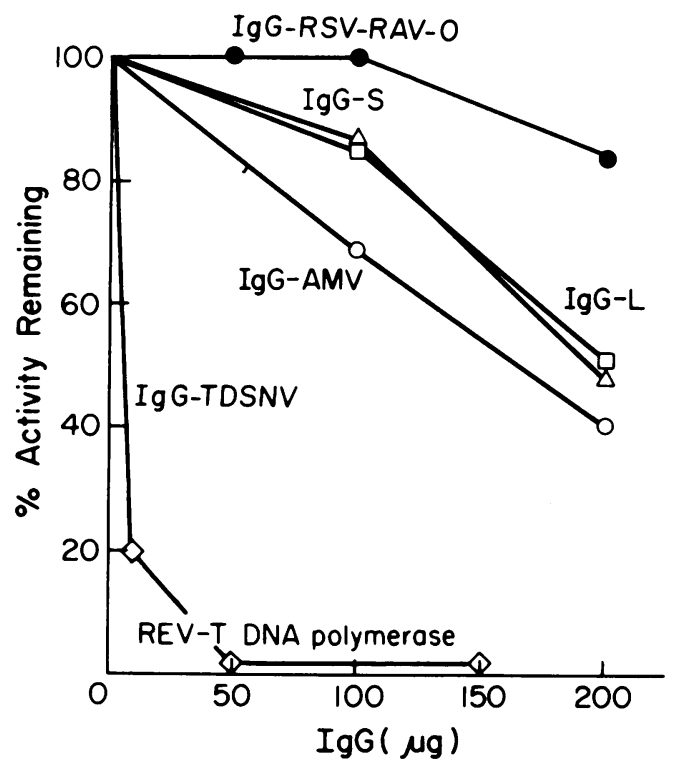

Fig. 3. Neutralization of partially purified REV-T DNA polymerase. The procedures described in the legend of Fig. 2 were followed with partially purified $R E V-T D N A$ polymerase. One hundred percent activity was 6,800 counts/min in a 20-min incubation. Symbols: IgG-TDSNV, ○; IgG-AMV, O; IgG-L, $\square$; IgG-S, $\triangle$; and IgG-RSV-RAV-0, 
heterologous antibodies, but was neutralized $(80 \%)$ by IgG-TDSNV (Table 1$)$.

Neutralization of partially purified DNA polymerases by IgG-TDSNV. IgG-TDSNV was incubated with ALV, chicken, and Pekin duck partially purified DNA polymerases to test for serological relationships. The activity of partially purified RSV-RAV-0 DNA polymerase was slightly neutralized (10 to $15 \%$ ) by IgGTDSNV only at high concentrations $(100 \mu \mathrm{g})$ of antibody (Fig. 4). In other experiments, the activities of partially purified B77 virus and Schmidt-Ruppin D RSV DNA polymerases were also slightly neutralized ( 10 to $20 \%$ ) by 200 $\mu \mathrm{g}$ of IgG-TDSNV (data not shown). The activity of chicken embryo large DNA polymerase was neutralized $30 \%$ by $5 \mu \mathrm{g}$ of IgG-TDSNV, but the activity of chicken embryo small DNA polymerase was not neutralized by even $200 \mu \mathrm{g}$ of IgG-TDSNV (Fig. 4). The activity of Pekin duck liver large DNA polymerase was in some experiments neutralized approximately $20 \%$ by $200 \mu \mathrm{g}$ of IgG-TDSNV (Fig. 4).

The activities of the Pekin duck liver small, the Muscovy duck liver large and small, the pheasant liver large and small, the turkey liver large and small, the rat liver large and small, and the $E$. coli DNA polymerases were not neutralized by $200 \mu \mathrm{g}$ of IgG-TDSNV, IgGAMV, or IgG-RSV-RAV-0 (data not shown).

Serological relationships among chicken, Pekin duck, Muscovy duck, pheasant, turkey, rat, and $E$. coli DNA polymerases. REV-T was isolated from turkeys and TDSNV from Pekin ducks. Therefore, experiments were performed with DNA polymerases from turkeys and Pekin ducks to determine if there were serological relationships to chicken DNA polymerases. DNA polymerases of pheasants,

TABLE 1. Neutralization of partially purified CSV DNA polymerase ${ }^{a}$

\begin{tabular}{c|c|c}
\hline \multirow{2}{*}{ IgG } & \multicolumn{2}{|c}{$\begin{array}{c}{\left[{ }^{3} \mathrm{H}\right] \mathrm{TMP} \text { incorporation }} \\
\text { (counts per min per 20 min) }\end{array}$} \\
\cline { 2 - 3 } & $0 \mu \mathrm{g}$ & $200 \mu \mathrm{g}$ \\
\hline IgG-TDSNV $\ldots \ldots \ldots \ldots \ldots$ & 9,600 & 1,800 \\
IgG-AMV $\ldots \ldots \ldots \ldots \ldots \ldots$ & 8,600 & 8,400 \\
IgG-L $\ldots \ldots \ldots \ldots \ldots \ldots$ & 7,700 & 7,800 \\
IgG-S $\ldots \ldots \ldots \ldots \ldots \ldots$ & 9,000 & 10,400 \\
IgG-RSV-RAV-0 $\ldots \ldots \ldots$ & 8,700 & 8,600 \\
\hline
\end{tabular}

${ }^{a}$ A 3- $\mu \mathrm{g}$ amount of partially purified CSV DNA polymerase was incubated separately at room temperature for $30 \mathrm{~min}$ in $30 \mu$ liters with 0 or $200 \mu \mathrm{g}$ of IgG-TDSNV, IgG-AMV, IgG-L, IgG-S, or IgG-RSVRAV-0. The amounts of DNA polymerase activity remaining were assayed in standard reaction mixtures containing activated calf thymus DNA.

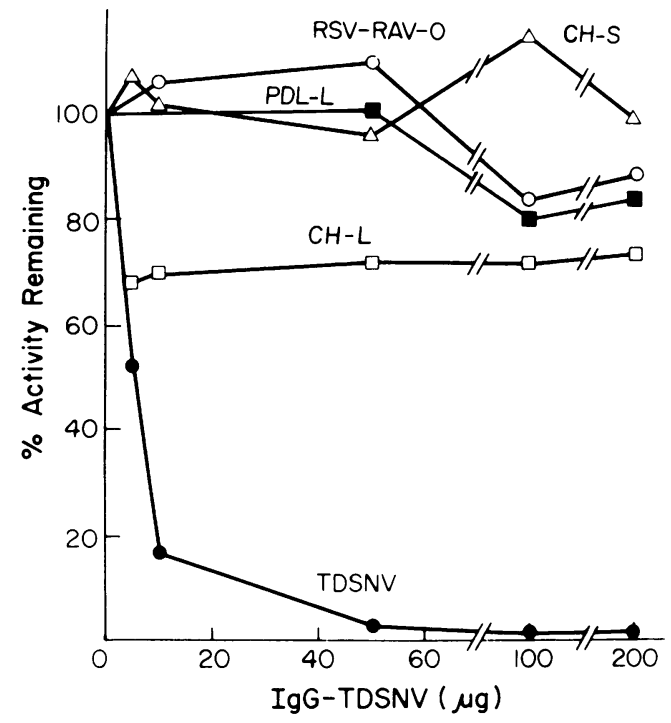

Fig. 4. Neutralization of partially purified DNA polymerases with IgG-TDSNV. Approximately similar amounts of TDSNV (O), RSV-RAV-O (O), Pekin duck large $(\square)$, chicken embryo large $(\square)$, or chicken embryo small $(\triangle)$ DNA polymerase activities ( $\left[{ }^{3} \mathrm{H}\right] d T M P$ incorporation: 20,000 to 60,000 counts per min per 20 min) were separately incubated with the indicated amounts of IgG-TDSNV at room temperature for $30 \mathrm{~min}$ in 30 uliters. The DNA polymerase activity remaining was assayed with activated calf thymus DNA as a template primer. Results are expressed as a percentage of the DNA polymerase activity remaining without incubation with antibody.

Muscovy ducks, rats, and $E$. coli were also studied. All the cellular DNA polymerases used for these neutralization studies were exposed to $0.5 \mathrm{M} \mathrm{KCl}$ in glycerol gradients. The salt dependency of the neutralization of the cellular DNA polymerases was not studied. Neutralization of large and small DNA polymerases partially purified from the soluble fractions of livers of these birds and rats and from $E$. coli was examined with antibodies previously prepared against the chicken large and small DNA polymerases (IgG-L and IgG-S) (Table 2).

The Pekin duck large DNA polymerase was neutralized by IgG-L. The Pekin duck and the turkey small DNA polymerases were neutralized by IgG-S. These neutralizations were confirmed in experiments by using a number of different antibody concentrations (up to 200 $\mu \mathrm{g} / 25 \mu$ liters). The curves of percent neutralization versus antibody concentration were almost the same as those in the homologous neutralizations (data not shown).

In addition, IgG-L $(200 \mu \mathrm{g})$ did not neutralize the activity of the DNA polymerases from Muscovy duck, pheasant, and turkey livers. 
IgG-S (50 $\mu \mathrm{g})$ neutralized $30 \%$ of the activity of the Muscovy duck large DNA polymerase, 70\% of the activity of the Muscovy duck small DNA polymerase, 20 to $25 \%$ of the activity of the pheasant small and large DNA polymerases, and $20 \%$ of the activity of the rat small DNA polymerase. For comparison, 2 to $5 \mu \mathrm{g}$ of IgG-L and $20 \mu \mathrm{g}$ of IgG-S neutralized over $90 \%$ of the activity of the homologous chicken DNA polymerases (5). No cross-reactions between the chicken large and small DNA polymerases were observed previously using neutralization tests (5).

No neutralization was found of the rat liver large or $E$. coli DNA polymerases.

Therefore, there are specific serological relationships among these avian DNA polymerases and between chicken and rat small DNA polymerases. Previously, it was reported that several mammalian large and small DNA polymerases are serologically related (1).

Antibody blocking activity. The antibody blocking activities of the partially purified DNA polymerases were studied to provide further evidence for serological relationships among REV, ALV, and avian DNA polymerases. The salt concentration in the DNA polymerase prep-

TABLE 2. Neutralization of partially purified pheasant, turkey, duck, and rat liver and E. coli DNA polymerases $^{a}$

\begin{tabular}{|c|c|c|}
\hline \multirow{2}{*}{ DNA polymerase } & \multicolumn{2}{|c|}{ Inhibition (\%) } \\
\hline & $\mathrm{IgG}-\mathrm{L}$ & IgG-S \\
\hline Pheasant liver & & \\
\hline Large & 0 & 25 \\
\hline Small & 0 & 20 \\
\hline Turkey liver & & \\
\hline Large ... & 0 & 0 \\
\hline Small & 0 & 95 \\
\hline Pekin duck liver & & \\
\hline Large ....... & 60 & 20 \\
\hline Small & 0 & 90 \\
\hline Muscovy duck liver & & \\
\hline Large & 0 & 30 \\
\hline Small & 0 & 70 \\
\hline Rat liver & & \\
\hline Large & 0 & 0 \\
\hline Small & 0 & 20 \\
\hline E. coli & 0 & 0 \\
\hline
\end{tabular}

${ }^{a}$ A 5-to-10 $\mu \mathrm{g}$ amount of each partially purified DNA polymerase was incubated in $30 \mu$ liters with 50 $\mu \mathrm{g}$ of each antibody at room temperature for $30 \mathrm{~min}$. The DNA polymerase activity remaining was assayed in a standard reaction mixture containing activated calf thymus DNA. $100 \%$ activity for each reaction was between 15,000 and 45,000 counts per min per $20 \mathrm{~min}$, except for the $E$. coli DNA polymerase which had a 100 -fold greater activity. arations was lowered by dialysis against $0.01 \mathrm{M}$ Tris buffer ( $\mathrm{pH}$ 7.5) before the blocking experiments to prevent a salt effect on DNA polymerase activity.

Constant amounts of IgG-L, IgG-AMV, or IgG-TDSNV were incubated with increasing amounts of several partially purified DNA polymerases. Then the antibody activity remain ing was assayed with the homologous DNA polymerases-IgG-L and chicken embryo large DNA polymerase; IgG-AMV and Carr-Zilberassociated virus DNA polymerase; and IgGTDSNV and TDSNV DNA polymerase.

IgG-L was blocked $50 \%$ by $10 \mu \mathrm{g}$ of chicken embryo large DNA polymerase, $50 \%$ by $4 \mu \mathrm{g}$ of REV-T DNA polymerase, and $40 \%$ by $12 \mu \mathrm{g}$ of TDSNV DNA polymerase (Fig. 5). (The chicken embryo large DNA polymerase was less pure than the REV-T DNA polymerase.) IgG-L was not significantly blocked by $20 \mu \mathrm{g}$ of chicken embryo small DNA polymerase, $15 \mu \mathrm{g}$ of rat liver large or small DNA polymerases, and $9 \mu \mathrm{g}$ of $E$. coli DNA polymerase I. (A slight serological relationship between chicken embryo large and small DNA polymerases was observed in antibody blocking tests with IgG-S and chicken embryo large DNA polymerase [data not shown].)

IgG-AMV was blocked $80 \%$ by $1 \mu \mathrm{g}$ of RSVRAV-0 DNA polymerase, $90 \%$ by $20 \mu \mathrm{g}$ of chicken embryo large DNA polymerase, $75 \%$ by $20 \mu \mathrm{g}$ of chicken embryo small DNA polymerase, $50 \%$ by $10 \mu \mathrm{g}$ of TDSNV DNA polymerase, and $25 \%$ by $4 \mu \mathrm{g}$ of REV-T DNA polymerase (Fig. 6). IgG-AMV was not blocked by $20 \mu \mathrm{g}$ of rat liver large DNA polymerase, rat liver small DNA polymerase, or $E$. coli DNA polymerase I.

IgG-TDSNV was blocked $70 \%$ by $1 \mu \mathrm{g}$ of TDSNV DNA polymerase and 30 to $50 \%$ by 10 $\mu \mathrm{g}$ of RSV-RAV-0, Pekin duck large, and chicken embryo large and small DNA polymerases (Fig. 7). Turkey liver large and rat liver large and small DNA polymerases blocked similarly (data not shown). IgG-TDSNV was not blocked by $8 \mu \mathrm{g}$ of HeLa cell large DNA polymerase or $20 \mu \mathrm{g}$ of $E$. coli DNA polymerase I (Fig. 7).

No blocking of IgG-L or IgG-AMV was found with $8 \mu \mathrm{g}$ of HeLa cell large DNA polymerase (data not shown).

These results are consistent with the neutralization data presented in Fig. 2, 3, and 4 and in Table 2.

The sum of these experiments (Table 3) indicates that reticuloendotheliosis virus DNA polymerases are serologically related specifically to avian leukosis-sarcoma virus DNA polymerases and to chicken embryo and Pekin duck liver DNA polymerases. 


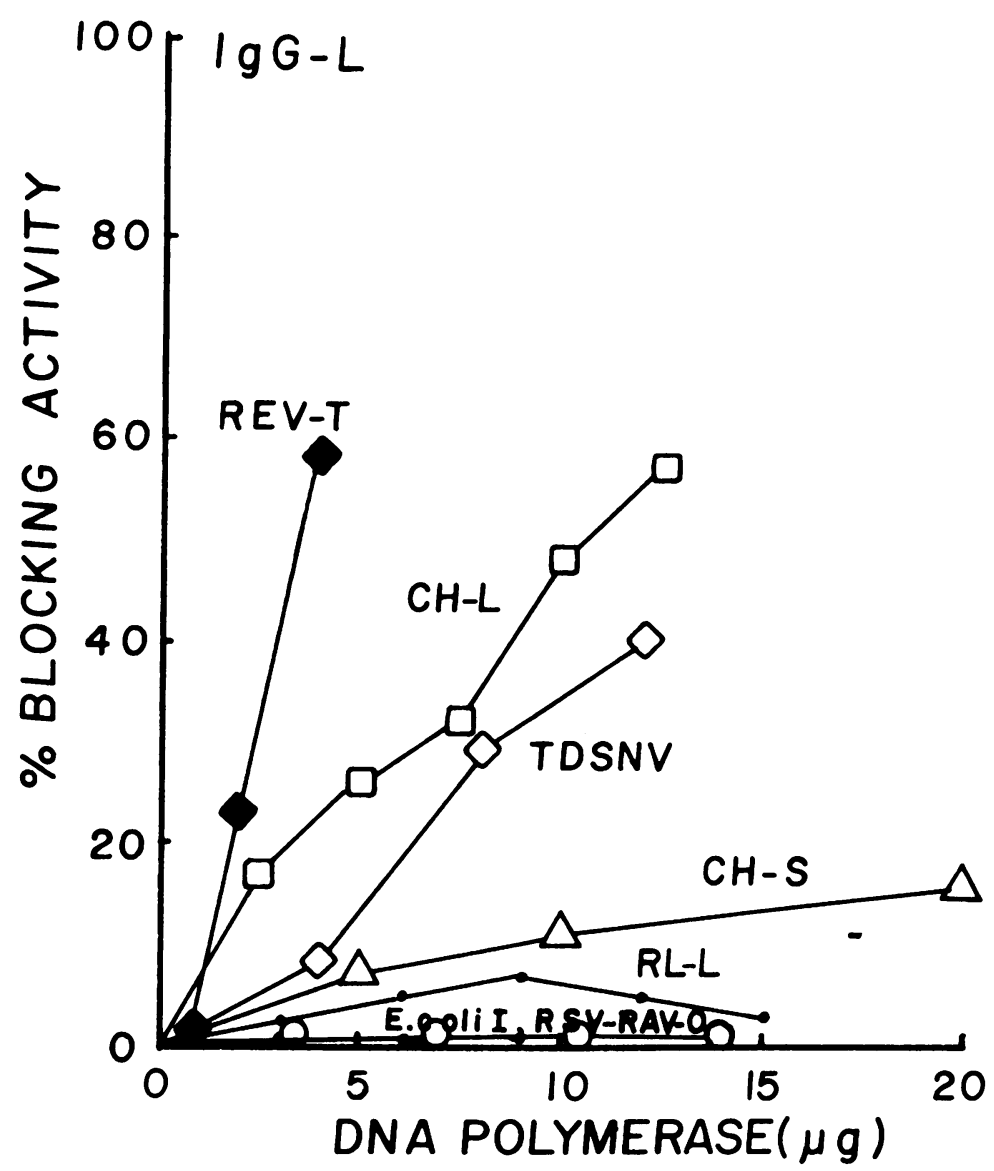

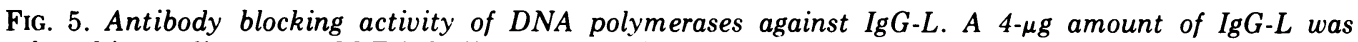
incubated in 25 uliters $(0.01 \mathrm{M}$ Tris buffer, $p H 7.5)$ with the indicated amounts of $R E V-T(\diamond)$, chicken embryo large $(\square), T D S N V(\diamond)$, chicken embryo small $(\Delta)$, rat liver large $(\cdot), R S V-R A V-0(O)$, and $E$. coli $(\cdot) D N A$ polymerases in the presence of $100 \mu \mathrm{g}$ of bovine serum albumin per $\mathrm{ml}$ at $37 \mathrm{C}$ for $20 \mathrm{~min}$. The $E$. coli DNA polymerase was inactivated by heating at $56 \mathrm{C}$ overnight before use. The same lack of blocking was found with native E. coli DNA polymerase. After incubation at $37 \mathrm{C}$ for $20 \mathrm{~min}$, the mixtures were heated at $56 \mathrm{C}$ for $30 \mathrm{~min}$ to inactivate the DNA polymerases. Partially purified chicken embryo large DNA polymerase $(4 \mu \mathrm{g}) \mathrm{was}$ then added to the incubation mixtures (total volume $30 \mu$ liters $[0.01 \mathrm{M}$ Tris buffer, pH 7.5, containing $0.03 \mathrm{M} \mathrm{KCl}]$ ), and the mixtures were incubated at room temperature for another $30 \mathrm{~min}$. The DNA polymerase activity remaining was assayed with activated calf thymus DNA as a template primer. The DNA polymerase activity remaining in the sample incubated without antibody $(30,000$ counts $/$ min) was set at $100 \%$ activity. Eighty percent of the chicken embryo large DNA polymerase activity was neutralized by $4 \mu \mathrm{g}$ of IgG-L. Zero percent blocking was defined as the percent activity remaining in the reaction without preincubation with DNA polymerases. The percentage of blocking was calculated as the percentage of increase in activity after preincubation with the DNA polymerases.

\section{DISCUSSION}

Specific serological relationships were found among the DNA polymerases of the two groups of avian viruses whose virions contain RNA and a DNA polymerase (the avian leukosis-sarcoma and reticuloendotheliosis viruses) and three avian species which are natural hosts for these viruses (chicken, turkey, and Pekin duck). In addition, serological relationships were found among TDSNV, chicken embryo small, and rat liver large and small DNA polymerases. Serological relationships between rat liver large and small DNA polymerases had been previously reported (1). No serological relationships were found with a HeLa cell DNA polymerase and an $E$. coli DNA polymerase.

Previously, using the DNA polymerase activity of disrupted virions, group-specific serological relationships were only found among the different reticuloendotheliosis viruses and among the different avian-leukosis sarcoma vi- 


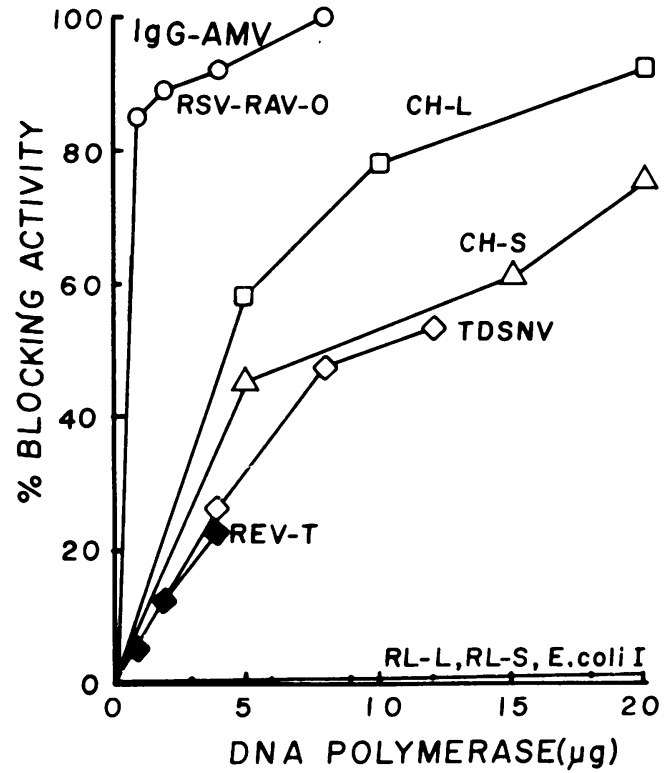

Fig. 6. Antibody blocking activity of DNA polymerases against IgG-AMV. A 2- $\mu$ g amount of IgG$A M V$ was incubated in $25 \mu$ liters with the indicated amounts of RSV-RAV-O (O), chicken embryo large $(\square)$, chicken embryo small $(\Delta), T D S N V(\diamond), R E V-T$ $(\triangleleft)$, rat liver large and small and $E$. coli (.) DNA polymerases as in the legend to Fig. 5. Partially purified Carr-Zilber associated virus DNA polymerase $(0.5 \mu g)$ was used to test for residual antibody activity. The DNA polymerase activity remaining in the sample incubated without antibody $(20,000$ counts/ min) was set at $100 \%$ activity. Seventy percent of the DNA polymerase activity was neutralized by the $2 \mu \mathrm{g}$ of $\operatorname{IgG}-A M V$. Calculations were done as described in the legend to Fig. 5.

ruses (5). The newly described serological relationships, which we shall call class-specific, were weaker and were seen only with partially purified DNA polymerases. In addition, only reticuloendotheliosis virus DNA polymerases exposed to a high salt concentration during purification showed these class-specific serological relationships, and CSV DNA polymerase showed no class-specific relationships. Among the class-specific serological relationships, some were seen both by neutralization and by blocking tests-between avian leukosis-sarcoma virus and reticuloendotheliosis virus DNA polymerases, and between chicken large and reticuloendotheliosis virus DNA polymerases. Others were only seen by blocking tests-between avian leukosis-sarcoma virus and chicken DNA polymerases, and between reticuloendotheliosis virus and turkey and duck large and chicken small DNA polymerases. The relationship between TDSNV DNA polymerase and rat liver large and small DNA polymerases reflects the relationships between chicken small DNA polymerase and rat small DNA polymerase, and between rat large and small DNA polymerases. No relationships were seen by neutralization and not by blocking.

There are some possible experimental problems with this data. (i) Reciprocal neutralizations were not always found. For example, IgGRSV-RAV-0 did not neutralize TDSNV DNA polymerase activity, and IgG-TDSNV only slightly neutralized RSV-RAV-0 DNA polymerase activity, whereas RSV-RAV-0 DNA polymerase was $10 \%$ as effective as TDSNV DNA polymerase in blocking the activity of IgGTDSNV; and RSV-RAV-0 DNA polymerase did not block IgG-L, whereas chicken embryo large DNA polymerase blocked IgG-AMV.

(ii) One hundred percent blocking was not found in the experiments of Fig. 5 and 7 even with the homologous antigens.

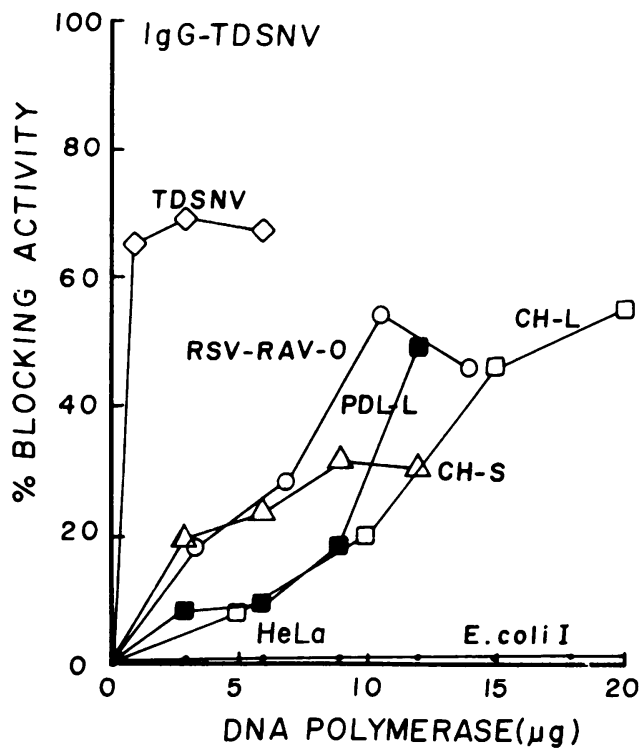

FIG. 7. Antibody blocking activity of DNA polym-

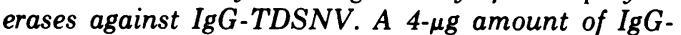
TDSNV was mixed with the indicated amounts of partially purified TDSNV (৩), RSV-RAV-O (O), Pekin duck large ( $\square)$, chicken embryo large ( $\square)$, chicken embryo small $(\Delta)$, and HeLa cell and $E$. coli (.) DNA polymerases as in the legend to Fig. 5. Partially purified TDSNV DNA polymerase $(2 \mu \mathrm{g})$ was added to these mixtures, and the mixtures were incubated at room temperature for $30 \mathrm{~min}$. The DNA polymerase activity remaining was assayed with activated calf thymus DNA as a template primer. The DNA polymerase activity remaining in the sample incubated without antibody $(45,000$ counts/min) was set at $100 \%$ activity. Seventy to $80 \%$ of the TDSNV DNA polymerase activity was neutralized by $4 \mu \mathrm{g}$ of IgG-TDSNV. Blocking activity was calculated as described in the legend of Fig. 5. 
TABLE 3. Summary of serological relationships among DNA polymerases

\begin{tabular}{|c|c|c|c|c|c|}
\hline \multirow{2}{*}{ DNA polymerase } & \multicolumn{5}{|c|}{ Antibody against partially purified DNA polymerase } \\
\hline & $\mathrm{CH}-\mathrm{L}$ & $\mathrm{CH}-\mathrm{S}$ & AMV & RSV-RAV-0 & TDSNV \\
\hline $\begin{array}{l}\text { Cell } \\
\text { Chicken-L } \\
\text { Chicken-S } \\
\text { Pheasant-L } \\
\text { Pheasant-S } \\
\text { Turkey-L } \\
\text { Turkey-S } \\
\text { Pekin duck-L } \\
\text { Pekin duck-S } \\
\text { Muscovy duck-L } \\
\text { Muscovy duck-S } \\
\text { Rat-L } \\
\text { Rat-S } \\
\text { HeLa-L } \\
\text { E. coli I }\end{array}$ & $\begin{array}{c}++^{a} \\
0 \\
- \\
- \\
- \\
- \\
++ \\
- \\
- \\
- \\
0 \\
0 \\
0 \\
0\end{array}$ & $\begin{array}{c} \pm \\
++ \\
+ \\
+ \\
- \\
++ \\
+ \\
++ \\
+ \\
++ \\
+ \\
+ \\
\text { NT } \\
-\end{array}$ & $\begin{array}{l} \pm \\
\pm \\
- \\
- \\
- \\
- \\
- \\
- \\
- \\
- \\
- \\
0 \\
0 \\
0 \\
0\end{array}$ & $\begin{array}{l}- \\
- \\
- \\
- \\
- \\
- \\
- \\
- \\
- \\
- \\
- \\
- \\
\text { NT } \\
-\end{array}$ & $\begin{array}{l}+ \\
\pm \\
- \\
- \\
\pm \\
- \\
\pm \\
- \\
- \\
- \\
\pm \\
\pm \\
0 \\
0\end{array}$ \\
\hline $\begin{array}{l}\text { Virus } \\
\text { RSV-RAV-0 } \\
\text { CSV } \\
\text { REV-T } \\
\text { TDSNV }\end{array}$ & $\begin{array}{l}0 \\
- \\
+ \\
+\end{array}$ & $\begin{array}{l}- \\
- \\
+ \\
+\end{array}$ & $\begin{array}{c}++ \\
- \\
+ \\
+\end{array}$ & $\begin{array}{c}++ \\
- \\
+ \\
+\end{array}$ & $\begin{array}{c}+ \\
++ \\
++ \\
++\end{array}$ \\
\hline
\end{tabular}

${ }^{a}++$, Strong cross-reaction; + , some neutralization; \pm , blocking, no neutralization; - , no neutralization, blocking not tested; 0 , no cross-reaction; NT, not tested.

${ }^{n}$ All ALV DNA polymerases were similar.

$c^{c}-$, With disrupted virions except for IgG-TDSNV.

(iii) Contamination of DNA polymerases might have occurred if cell polymerases contaminated REV or REV infected the chicken embryos, or if ALV contaminated REV or REV contaminated ALV.

It is unlikely that cell DNA polymerases contaminated REV virions. All virions were prepared and were purified in the same fashion by sucrose density gradient centrifugation. However, the cross-reactions of the different REV DNA polymerases differed (Fig. 2 and 3, Table 1). Furthermore, the quantities of IgG-S and IgG-L required to neutralize the REV DNA polymerases were 100 times larger than required to neutralize the homologous cell DNA polymerases.

It is unlikely that REV was present in the chicken embryos. Chickens have not been found to have natural antibodies to REV (8), and chicken DNA does not have many of REV RNA sequences. REV did not contaminate the turkey or Pekin duck livers used for DNA polymerase preparation by nucleic acid hybridization tests (Kang, personal communication).

It is unlikely that ALV contaminated REV or that REV contaminated ALV. REV has not been studied in the laboratory where the AMV used to prepare IgG-AMV was grown. All other viruses used in this study were monitored for contamination by nucleic acid hybridization. No contamination was found. The nucleic acid hybridization technique used has proven capable of recognizing $0.01 \%$ contamination of $\mathrm{REV}$ by ALV (Kang, personal communication).

We believe that these possible problems do not affect our results and that the serological relationships between ALV and REV DNA polymerases, and between ALV, REV, and avian cell DNA polymerases discussed above, (Table 3) are real.

These serological relationships could result from evolutionary links and/or recombinational events. The relationships among the avian cell DNA polymerases and between the chicken and rat small DNA polymerases probably reflect evolutionary relationships. Possibly, the relationships between the ALV and the REV DNA polymerases and between the ALV, the REV, and the avian cell DNA polymerases result from both causes. Recombination between avian leukosis-sarcoma viruses and cells seems to be well documented (H. M. Temin, Advan. Cancer Res., 19:47-104, 1974). Evolution from normal cell components of RNA viruses whose virions contain a DNA polymerase $(10 ; \mathrm{H}$. M. Temin, Advan. Cancer Res., 19:47-104, 1974) seems 
also a real possibility. Further studies of these DNA polymerases may enable these and other hypotheses to be tested.

\section{ACKNOWLEDGMENTS}

We wish to thank G. Cooper. D. Zarling, and R. C. Nowinski for critical comments on the manuscript, and $\mathrm{M}$. McKeough and V. Kassner for technical assistance.

This investigation was supported by Public Health Service Research grant CA-07175 from the National Cancer Institute and grant VC-7 from the American Cancer Society. S. Mizutani is a scholar of the Leukemia Society of America. H. M. Temin holds Research Career Development Award CA-5002 from the National Cancer Institute.

\section{LITERATURE CITED}

1. Chang, L. M. S., and F. J. Bollum. 1972. Antigenic relationships in mammalian DNA polymerase. Science 175:1116-1117.

2. Halpern. M. S., E. Wade, E. Rucker, K. L. Baxter-Gabbard, A. S. Levine, and R. R. Friis. 1973. A study of the relationship of reticuloendotheliosis virus to the avian leukosis-sarcoma complex of viruses. Virology 53:287-299.

3. Kang. C.-Y., and H. M. Temin. 1973. Study of sequence homology among RNAs of avian leukosis viruses, reticuloendotheliosis viruses, and chicken endogenous RNA-directed DNA polymerase activity. J. Virol. 12:1314-1324.

4. Maldomado. R. L., and H. R. Bose. 1973. Relationship of reticuloendotheliosis virus to the avian tumor viruses: nucleic acid and polypeptide composition. J. Virol. 11:741-747.
5. Mizutani, S., and H. M. Temin. 1973. Lack of serological relationship among DNA polymerases of avian leukosis-sarcoma viruses, reticuloendotheliosis viruses, and chicken cells. J. Virol. 12:440-448.

6. Nowinski, R. C., K. F. Watson, A. Yaniv, and S Spiegelman. 1972. Analysis of deoxyribonucleic acid polymerase of avian onco-RNA viruses. II. Comparison of avian deoxyribonucleic acid polymerases. J. Virol. 10:959-964.

7. Peterson, D. A., K. L. Baxter-Gabbard, and A. S. Levine. 1972. Avian reticuloendotheliosis virus (strain T). V. DNA polymerase. Virology 47:251-254.

8. Purchase, H. G.. G. Ludford, K. Nazarian, and H. W. Cox. 1973. A new group of oncogenic viruses: reticuloendotheliosis, chick syncytial, duck infectious anemia, and spleen necrosis viruses. J. Nat. Cancer Inst. 51:489-499.

9. Schlaback, A., B. Fridlander, A. Bolden, and A. Weissbach. 1971. DNA dependent DNA polymerases from HeLa cell nuclei. II. Template and substrate utilization. Biochem. Biophys. Res. Commun. 44:879-885.

10. Temin, H. M. 1970. Malignant transformation of cells by viruses. Perspect. Biol. Med. 14:11-26.

11. Temin, H. M., and D. Baltimore. 1972. RNA-directed DNA synthesis and RNA tumor viruses, p. 129-186. In K. M. Smith, M. A. Lauffer, and F. B. Bang (ed.). Advances in virus research, vol. 17. Academic Press Inc.. New York.

12. Temin, H. M., and V. Kassner. 1974. Replication of reticuloendotheliosis viruses in cell culture: acute infection. J. Virol. 13:291-298.

13. Temin, H. M., and S. Mizutani. 1970. RNA-dependent DNA polymerase in virions of Rous sarcoma virus. Nature (London) 226:1211-1213. 